\title{
ЗАРУБІЖНИЙ ДОСВЦД РЕГЛАМЕНТАЦІї КРИМІНАЛЬНОЇ ВІДПОВІДАЛЬНОСТІ ЗА НАЙМАНСТВО
}

\author{
МАРТЬЯНОВ Сергій Сергійович - аспірант кафедри кримінального права \\ та процесу Львівського торговельно-економічного університету
}

DOI:10.32782/NP.2020.1.23

Анализируются вопросъ уголовной ответственности за наемничество по уголовному законодательству зарубежньгх государств. На основании анализа предписаний уголовного законодательства отдельнъих европейских и постсоветских государств констатируются общие и отличительнье черть нормативного урегулирования этого вопроса. Ввиказълвается авторская точка зрения о челесообразности имплементации некоторьх положений зарубежного законодательства в отечественное. Определень степень научной разработ$к и$ вопросъ уголовной ответственности за наемничество. Дается характеристика наемничества как преступления против мира и безопасности человечества. Путем анализа элементов состава преступления акцентируется внимание на особенностях совершенствования Уголовного кодекса Украинъ.

Въцделенъ положения, которье являются неудачнълми (в которьих не указана цель вербовки, Финансирования, обучения или иного материального обеспечения наемника; где сужен круг преступнъх действий, охватьлваемых понятием «наемничество»). Рассмотрено объективную сторону состава наемничества и определенъ особенности субъективной сторонъл. Охарактеризован субъект наемничества по УК зарубежнъих государств.

Ключевъие слова: наемничество, наемник, уголовная ответственность, зарубежный опьтт, субъект преступления.

\section{Постановка проблеми}

Умови сучасного світу, хиткість його існування потребують встановлення нових відносин співробітництва у сфері боротьби зі злочинністю як світового, так і регіонального характеру. Для цього не слід змінювати національні правові системи одноманітним наднаціональним правом, а необхідно напрацювати єдині кримінально-правові матеріальні норми, інститути та категорії, які регулюють глобальні міжнародні правовідносини, а також визначити єдиний понятійний правовий механізм [1, с.4]. Не є виключенням у цьому випадку регламентація питань кримінальної відповідальності за найманство, яке набуває нових форм та виступає рушійною силою агреciï. Не можна заперечувати того, що проблема протидії найманству на міжнародному рівні піднімається з новою силою, оскільки у різних куточках планети, де мають місце збройні протистояння, міжнародні спостерігачі фіксують присутність спеціально завербованих іноземців професіоналів, які беруть участь у насильницьких акціях із метою дестабілізації громадської безпеки тієї чи іншої держави або зміни її конституційного ладу. Відтак вивчення та порівняння законодавства зарубіжних держав у цій частині $є$ важливим з огляду на те, що такий аналіз надасть можливість побачити переваги та недоліки національних законотворчих традицій, а відтак окреслити напрями вдосконалення КК України та запозичити позитивний правовий досвід. Слід погодитись із В.О.Навроцьким, який зауважує, що вивчення норм Особливої частини кримінального законодавства зарубіжних держав дозволяє виявити недоліки вітчизняного права, які насправді не відповідають сучасним 
нормам, що діють в інших державах, а також знайти аргументи для відстоювання тих позицій, поступатися якими, з урахуванням національної специфіки та сучасних проблем, видається недоцільним [2, с.4].

\section{Стан дослідження}

Загалом дослідження проблеми найманства носить міжгалузевий характер, оскільки здійснювались 3 позицій міжнародного права, політології, теорії та історії держави і права, а також кримінального права.3 огляду на зазначене вивчені джерела необхідно згрупувати у дві групи. Перша група теоретичних напрацювань стосується міжнародно-правової регламентації боротьби 3 найманством, а також правового регулювання діяльності приватних військових та охоронних підприємств. Мова йде про роботи таких вчених як К.В. Громовенка,I.O. Колотухи, І.Л. Невзорова, А.О. Павлової, П.І. Репешка, О.О. Скрильника та інших. Друга група наукових досліджень охоплюе праці, які стосуються кримінально-правової характеристики найманства. Деякі аспекти цієі проблеми розглядали у працях А.О. Купріянова, С.М. Мохончука, Т.I. Нікіфорова, К.В. Юртаєва та інші. Слід віддати належне монографічному дослідженню О.В. Наден, у якому автор розглядає найманство як соціальне та кримінальноправове явище, аналізує сучасні проблеми розвитку протиправної військової служби та найманства як його складової частини, а також характеризує найманство 3 погляду принципів міжнародного права. Втім доводиться констатувати, що ніхто з авторів не здійснював порівняльно-правового аналізу кримінально-правової протидії найманству, не оцінював ефективність відповідної норми у КК зарубіжних держав.

Таким чином, основною метою цієї статті є вивчення зарубіжного досвіду регламентації кримінальної відповідальності за найманство.

Виклад основних положень

Загальновідомо, що у світі існує близько двохсот держав, кримінальне законодавство кожної з яких має свою специфіку. 3 огляду на поступову реалізацію курсу України на вхо- дження до Європейської спільноти, необхідно вивчити кримінальне законодавство окремих держав, які є членами Европейського Союзу (Польща [3], ФРН [4], Австрія [5], Швеція [6], Франція [7], Бельгія [8], Іспанія [9], Італія [10], Болгарія [11], Данія [12]). Також варто зупинитися на аналізі положень кримінального законодавства держав пострадянського простору (Азербайджан [13], Білорусь [14], Вірменія [15], Грузія [16], Казахстан [17], Киргизстан [18], Молдова [19], Таджикистан [20], Узбекистан [21]). Власне такий вибір обумовлений низкою обставин, серед яких, передусім, подібність ідей реформування кримінального законодавства, його основних інститутів та спільність історичної правової системи.

Насамперед, потребує вивчення питання, чи взагалі регламентована відповідальність за найманство у кримінальному законодавстві зарубіжних держав. Аналіз КК держав, які входили до складу колишнього Радянського Союзу засвідчує, що законодавець встановлює кримінально-правову заборону на вчинення аналізованого злочину. Зокрема, відповідальність за найманство передбачена у наступних розділах: «Злочини проти миру i безпеки людства» (КК Киргизстану, Узбекистану, Азербайджану, Таджикистану, Вірменії, Казахстану), «Військові злочини та інші порушення законів і звичаїв ведення війни» (КК Білорусь), «Злочини проти людяності» (КК Грузії), «Злочини проти миру і безпеки людства, військові злочини» (КК Молдови).

Щодо кримінального законодавства держав, які є членами EC, то там спостерігається дещо інша картина. Законотворець у жодному $з$ розглянутих КК не закріплює термінів «найманець» чи «найманство» (виняток становить КК Франції). Водночас, незважаючи на це, доводиться констатувати, що зі змісту диспозицій статей, які регламентують кримінальну відповідальність за незаконну військову службу, випливає, що законодавець усе ж встановлюе кримінально-правову заборону за найманську діяльність (парагр. 109 h ФРН, ст.12 Глави 19 Швеції, ч.2 парагр.102 КК Данії, ст.141 КК Польщі, ст.288 КК Італії, ст.4361, ст.436-2 КК Франції). Так, за КК Швеції покаранню підлягає особа, яка в межах Королівства і без дозволу Уряду вербує людей для іноземної військової або іншої подібної служ- 
Мартьянов С.С. - Зарубіжний досвід регламентації кримінальної відповідальності...

би, або схиляє людей незаконно покинути країну для того, щоб вступити на таку службу (ст.12 Глави 19). Схоже положення передбачено у КК ФРН: «Хто вербує громадянина Нiмеччини на військову службу у воєнний або йому подібний заклад в інтересах іноземної держави або доставляє його вербувальникам або на військову службу подібної установи...» (парагр.109 h). Кримінально-караними визнаються також дії громадянина Польщі, який приймає на себе без згоди компетентного органу військові обов'язки в іноземній армії або іноземній військовій організації (ст.141 КК Польщі).

У подальшому необхідно встановити ознаки об'єктивної сторони складу найманства у кримінальному законодавстві зарубіжних держав. Практично у всіх випадках аналізоване посягання розглядається як злочин із формальним складом. Аише у КК Казахстану (ст.162) передбачені суспільно-небезпечні наслідки у виді загибелі людей або інші тяжкі наслідки, що свідчить про наявність матеріального складу. За КК держав пострадянського простору з об'єктивної сторони найманство передбачене у наступних формах: вербування, навчання, фінансування або інше матеріальне забезпечення найманця, а також його використання та участь у збройному конфлікті або військових операціях (ст.395 КК Вірменії, ст.132 КК Білорусь, ст.162 КК Казахстану, ст.141 КК Молдови, ст.114 КК Азербайджану, ст.410 КК Грузії, ст.375 КК Киргизстану, ст.401 КК Таджикистану).

Така схожість законодавчих конструкцій обумовлена тим, що у період розпаду СРСР була фактично однакова нормативна база пострадянських держав. Втім навряд чи можна стверджувати про відсутність відмінностей у сфері законодавчого регулювання питань кримінальної відповідальності, оскільки нормативна база кожної держави постійно вдосконалювалась та зазнавала змін. Прикладом цьому слугує ч.2 ст.154 КК Узбекистану, де вербування, навчання, фінансування або інше матеріальне забезпечення найманця, а також його використання у збройному конфлікті або військових діях виступає кваліфікуючою ознакою найманства. В основному же складі злочину регламентована кримінально-правова заборона найманства, тобто участі на терито- рії або стороні іноземної держави у збройному конфлікті або військових діях особи, яка не є громадянином або військовослужбовцям держави, що знаходиться в конфлікті, або постійно не проживає на території, яка контролюється стороною, що перебуває в конфлікті, або не уповноважена жодною державою для виконання офіційних обов'язків у складі збройних сил, $з$ метою отримання матеріальної винагороди чи інших особистих вигод (ч.1 ст.154). Аише за КК Білорусь кримінальна відповідальність за найманську діяльність передбачена у різних кримінально-правових нормах (ст.132 - вербування, навчання, фінансування або використання найманців;ст. 133 - найманство).

У КК держав, які є членами СС законодавець дещо звузив коло злочинних дій, які охоплюються поняттям «найманство». Зокрема, кримінально-караними визнаються наступні дії: вербування людей для іноземної військової або іншої подібної служби або схиляння їх незаконно покинути державу для того, щоб поступити на таку службу (ст.12 Глави 19 КК Швеції), вербування громадянина на військову службу або воєнний чи йому подібний заклад чи доставка його на таку службу (ст.109 h КК ФРН), вербування для служби в збройних силах будь-якої ворожої держави або сама служба в час війни або окупації у ворожих збройних силах або у взаємодіючих військових або поліцейських силах, або в будь-яких подібних структурних підрозділах, або організаціях (п.2 ч.2 парагр. 102 КК Даніï), недозволене вербування або озброєння в інтересах іноземної держави (ст.288 КК Італіiі). Такий підхід, вочевидь, не можна вважати вдалим, оскільки найманська діяльність не обмежується лише самим вербуванням, а потребує фінансування, матеріально-технічного забезпечення. Врешті-решт, не всі найманці відразу володіють навиками у «мистецтві ведення бойових дій», а тому потребують підготовки, навчання, що також повинно визнаватись кримінально-караним діянням. Дещо відрізняються у цьому випадку положення КК Франції, де встановлена кримінально-правова заборона участі найманця у збройному конфлікті і військових операціях (ст.436-1). Кримінально-караними також визнаються організація і управління угрупуванням, ме- 


\section{Кримінальне право, кримінальний процес та криміналістика}

тою якого є вербування, найм, екіпіровка, фінансування, військовий інструктаж особи найманця (ст.436-2).

Необхідно також зупинитись на вивченні ознак суб'єкта складу найманства, який може бути як загальним (ст.12 Глави 19 КК Швеції, парагр. 109 һ ФРН, п.1 ч.2 парагр. 102 КК Данії, ст.436-1, ст.436-2 КК Франції, ст.141КК Польщі, ст.288 КК Італії, ч.1 ст.375 КК Киргизстан, ч.1, п.2 ч.2 ст.395 КК Вірменії, ч.1 ст.114 КК Азербайджану, ч.1 ст.410 КК Грузї, ст.132 КК Білорусії, ч.1 ст.162 КК Казахстану, ч.2 ст.141 КК Молдови, ч.1 ст.401 КК Таджикистану, ч.2 ст.154 КК Узбекистану), так і спеціальним (чп.1 ч.2, ч.3 ст.395 КК Вірменії, ст.133 КК Білорусії, ч.2,3 ст.410 КК Грузії, ч.2, 3 ст.114 КК Азербайджану, ч.2, 3 ст.375 КК Киргизстану, ч.2, 3 ст.162 КК Казахстану, ч.1 ст.141 КК Молдови, ч.1 ст.154 КК Узбекистану, ч.2, 3 ст.401 КК Таджикистану), яким визнається службова особа, яка здійснює вербування, навчання, фінансування або інше матеріальне забезпечення найманця, а також його використання у збройному конфлікті або військових діях. Окрім того, ознаками спеціального суб'єкта наділений найманець. Дефініція цього поняття передбачена практично у всіх КК держав пострадянського простору. Зокрема, ним $є$ особа, яка діє з метою отримання матеріальної винагороди і не є громадянином держави, що бере участь у збройному конфлікті або військових операціях, не проживає постійно на його території, а також не є особою, спрямованою для виконання офіційних обов'язків (ч.2 примітки до ст.114 КК Азербайджану, примітка до ст.410 КК Грузії, примітка до ст.162 КК Казахстану, примітка до ст.375 КК Киргизстану, ст.130 КК Молдови, ст.154 КК Узбекистану). Найманці не включені до особового складу збройних сил держави, яка перебуває в конфлікті (ч.4 ст.395 КК Вірменії, примітка до ст.401 КК Таджикистану) та беруть участь у збройному конфлікті без уповноваження держави, громадянином якої вони є або на території якого постійно проживають (ст.133 КК Білорусь). Окрім того, відповідно до КК Франції суб'єктом складу найманства може виступати також юридична особа (ст.436-4). Така позиція законодавця, безсумнівно, є справедливою, оскільки нерідко діяльність найманців фінансується юридичною особою або ж може здійснюватись в ії інтересах. Прикладом цьому $є$ злочинна діяльність так званого Бюро у Парижі, яке займалось вербуванням найманців для участі у бойових діях у Конго та у 1961 р. було закрито.

Не менш важливим є питання щодо визначення форми вини найманства за законодавством зарубіжних держав. Незважаючи на те, що відповідь на це питання прямо не вказана у диспозиції статті, втім, виходячи із аналізу конструкції аналізованого складу злочину, можна говорити про прямий умисел, оскільки здійснення вербування найманців, їх фінансування, матеріальне забезпечення та навчання $є$ неможливе у формі необережності, адже така особа усвідомлюе суспільну небезпечність своїх дій та бажає їх вчинити. Те ж саме стосується участі найманця у збройному конфлікті або військових операціях, оскільки власне метою такої злочинної діяльності є отримання матеріальної вигоди. Так, відповідно до КК Франції кримінальнокараними є дії будь-якої особи, яка спеціально притягнула в якості найманця до участі у збройному конфлікті (ч.1 ст.436-1) або будьякої особи, яка є спеціально завербованою 3 метою прийняття участі в конкретній військовій операції, що має своєю метою повалення державних інститутів або спробу порушення територіальної цілісності держави (ч.2 ст.4361). За КК Білорусі вербування, навчання, фінансування, інше матеріальне забезпечення та використання найманців здійснюється для участі у військових діях проти іноземної держави або для протидії законному здійсненню права народів на самовизначення, визнаного міжнародним правом (ст.132).

Разом із тим, варто звернути увагу на те, що у кримінальному законодавстві переважної більшості зарубіжних держав пострадянського простору законотворець не зазначає, 3 якою метою здійснюється вербування, фінансування, навчання або інше матеріальне забезпечення найманця (ст.114 КК Азербайджану, ст.395 КК Вірменії, ст.410 КК Грузї, ст.162 КК Казахстану, ст.375 КК Киргизстану, ст.141 КК Молдови, ст.401 КК Таджикистану, ст.154 КК Узбекистану). Мабуть, такий стан речей можна пояснити власне тим, що у примітках до статей про найманство зазначено про те, що найманець бере участь у збройному конфлікті 
або військових операціях. Водночас такий підхід законодавця не можна вважати послідовним, оскільки, припустимо, особа, яка навчає найманців мистецтву ведення бойових дій, повинна чітко усвідомлювати, що здійснює це виключно з метою їх подальшого використання у збройних конфліктах інших держав чи насильницьких діях, а не для захисту тієї чи іншої держави в якості добровольця. 3 огляду на це вважаємо, що законодавцю необхідно у диспозиціях відповідних статей конкретизувати $з$ якою метою здійснюється вербування, фінансування, навчання або інше матеріальне забезпечення найманця, оскільки якщо така мета відсутня, то навряд чи правильно говорити про наявність у діях особи ознак складу найманства.

\section{Висновки}

Зарубіжний досвід регламентації кримінальної відповідальності дає змогу зробити висновок про те, що власне невдалими слід вважати положення кримінального законодавства тих держав, у яких не зазначена мета вербування, фінансування, навчання або іншого матеріального забезпечення найманця (ст.114 КК Азербайджану, ст.395 КК Вірменії, ст.410 КК Грузії, ст.162 КК Казахстану, ст.375 КК Киргизстану, ст.141 КК Молдови, ст.401 КК Таджикистану, ст.154 КК Узбекистану). Не вартим для запозичення також є досвід КК тих держав (ст.12 Глави 19 КК Швеції, ст.109 h КК ФРН, п.2 ч.2 парагр. 102 КК Данії, ст.288 КК Італії), де звужено коло злочинних дій, які охоплюються поняттям «найманство». Таким чином, порівняльно-правове дослідження в частині нормативного регулювання кримінальної відповідальності за найманство дозволило виявити не лише спільні закономірності правового розвитку, але й оцінити ефективність відповідної норми.

\section{入iтература}

1. Мелешко Н. П. Уголовно-правовые системы России и зарубежных стран / Н. П. Мелешко, Е.Г. Тарло. - М. : Юрлитинформ, 2003. $-304 \mathrm{c}$.

2. Навроцький В.О. Кримінальне законодавство зарубіжних держав: питання особливої частини - Аьвів: юридичний фа- культет Аьвівського державного університету ім. Івана Франка. - 1999. - 56 с.

3. Уголовный кодекс Республики Польша / пер. с польск. Д. А. Барилович и др.; адапт. пер. и науч. ред. Э. А. Саркисова, А. И. Аукашов; под общ. ред. Н. Ф. Кузнецовой. Мн.: Тесей, 2009. 128 с.

4. Уголовный кодекс ФРГ / пер. с нем. М.: Издательство «Зерцало», 2000. 208 с.

5. Уголовный кодекс Австрии / науч. ред. и вступ. статья докт. юрид. наук, проф. С.В. Милюкова; предисловие Генерального прокурора Австрии, доктора Эриста Ойгена Фабрици; перевод с немецкого $\mathcal{A}$. С. Вихровой. СПб.: Издательство «Юридический центр Пресс», 2004. 352 c.

6. Уголовный кодекс Швеции / пер. с англ. С. С. Беляэва. М., 2000. 167 с.

7. Уголовный кодекс Франции / науч. редактирование канд. юрид. наук, доц. А. В. Головко, канд. юрид. наук., доц. Н. Е. Крыловой; перевод с французского и предисловие канд. юрид. наук., доц. Н. Е. Крыловой. СПб.: Издательство «Юридический центр Пресс», 2002. $650 \mathrm{c}$.

8. Уголовный кодекс Бельгии / науч. ред. и предисл. Н. И. Мацнева; пер. с фр. Г. И. Мачковского. СПб.: Юридический центр Пресс, $2004.560 \mathrm{c}$.

9. Уголовный кодекс Испании / под редакцией и с предисловием доктора юридических наук, профессора Н. Ф. Кузнецовой и доктора юридических наук, профессора Ф. М. Решетникова. М.: Издательство «Зерцало», 1998. $218 \mathrm{c}$.

10. Уголовный кодекс Италии / пер. с англ. С. С. Беляэва. M., 2008. URL: http://www. altalex. com/?idnot $=36653$.

11. Уголовный кодекс Республики Болгария / науч. ред. канд. юрид. наук, проф. А. И. Аукашова; перевод с болгарского Д. В. Милушева, А. И. Аукашова; вступ. статья И. И. Айдарова. СПб.: Издательство «Юридический центр Пресс», 2001. 298 с.

12. Уголовный кодекс Дании : принят в 1930 г. : распоряжение № 648 от 12.08.1997 г. с изм., внес. Законом № 403 от 26.06.1998 г., Законом № 473 от 01.07.1998 г. и Законом № 141 от 17.03.1999 г. / Юридическая Россия - образовательный правовой портал. URL : https://goo.gl/XaPqr5. 


\section{АНОТАЦІЯ}

Аналізуються питання кримінальної відповідальності за найманство за кримінальним законодавством зарубіжних держав. На підставі аналізу приписів кримінального законодавства окремих європейсъких $i$ пострадянсъких держав констатуються спільні $і$ відмінні риси нормативного урегулювання изого питання. Висловлюеться авторсъка точка зору щодо доцільності імплементацій деяких положень зарубіжного законодавства у вітчизняне. Окреслено ступінь наукової розробки питання кримінальної відповідальності за найманство. Дається характеристика найманства як злочину проти миру $i$ безпеки людства. Шляхом аналізу елементів складу злочину акцентується увага на особливостях удосконалення Кримінального кодексу україни.

Виокремлено положення, які є невдалими (у яких не зазначена мета вербування, бінансування, навчання або іншого матеріального забезпечення наймания; де звужено коло злочинних дій, які охоплюються поняттям «найманство»). Розглянуто об'єктивну сторону складу найманства та визначено особливості суб'єктивной сторони. Охарактеризовано суб'єктів найманства за КК зарубіжних держав.

Ключові слова: найманство, найманець, кримінальна відповідальність, зарубіжний досвід, суб'єкт злочину.

13. Уголовный кодекс Азербайджанской Республики / науч. ред. И. М. Рагимова; перевод с азербайджанского Б. Э. Аббасова. СПб.: Издательство «Юридический центр Пресс», 2001. 325 c.

14. Уголовный кодекс Республики Беларусь / предисловие проф. Б. В. Волженкина; обзорная статья А. В. Баркова. СПб.: «Юридический центр Пресс», 2001. 474 с.

15. Уголовный кодекс Республики Армения / Е. Р. Азаряна, Н. И. Мацнева; предисловие Е. Р. Азаряна; перевод с армянского Р. 3. Авакяна. СПб.: Изд-во Р. Асланова «Юридический Центр Пресс», 2004. 450 с.

16. Уголовный кодекс Грузии / науч. ред. 3. К. Бигвава. СПб.: Издательство «Юридический Центр Пресс», 2002. 409 с.

17. Уголовный кодекс Республики Казахстан от 16 июля 1997 г. № 167/ предисловие министра юстиции Республики Казахстан

\section{SUMMARY}

This paper examines the intermational experience of regulation of criminal responsibility for mercenarism. On the basis of analysis of orders criminal legislation separate European and most post-Soviet countries the general and excellent lines of the normative regulation this question. Problematic issues and ways of their elimination are determined. The author point of view speaks out in relation to expedience of implementation of some positions of foreign legislation in domestic practice.

It defines bases of criminalization of mercenaries at the international level and ascertains the lack of global consensus on this issue. The objective-subjective side of the mercenary activities as the crime against peace and security of mankind has been analyzed. The peculiarities of the mercenary activities definition in the Criminal Code of Ukraine have been given special attention.

The statements that are worthy to be adopted by and to Ukrainian lawmaker (anticipation of such a qualifying sign of mercenary use of a minor), as well as those which are unsuccessful (which do not specify the purpose of recruitment, financing, training or other financial support of the mercenary; where the range of criminal activities covered by the concept of "mercenary" is narrowed) have been elucidated. The actus reus of the mercenarism according to the criminal legislation of the international experience is considered.

Key words: mercenarism, mercenary, criminal responsibility, foreign experience, subject of the crime.

докт. юрид. наук, проф. И. И. Рогова. Ведомости Парламента РК. 1997. № 15-16. СПб.: Издательство «Юридический Центр Пресс», 2001. 466 c.

18. Уголовный кодекс Кыргыской Республики.URL: www.toktom.kg/ lawcoll/15076.1.htm.

19. Уголовный кодекс Республики Молдова / вступительная статья А. И. Аукашова. СПб.: Изд-во «Юридический Центр Пресс», 2003. 408 c.

20. Уголовный кодекс Республики Таджикистан. СПб.: Юрид. Центр Пресс, 2001. 410с.

21. Уголовный кодекс Республики Узбекистан (с изм. и доп. на 15 июля 2001 г./ вступ. статья М. Х. Рустамбаева, А. С. Якубова, 3. Х. Гулямова. СПб.: Издательство «Юридический центр Пресс», 2001. - 338 с. 